\title{
SCIENTIFIC AND ENGINEERING MANPOWER IN THE UNITED STATES
}

\begin{abstract}
HE report of the Committee on the Utilization of Scientific and Engineering Manpower in the United States*, which is discussed on p. 1101 of this issue of Nature, bases its recommendations and conclusions largely on the facts set forth in the second chapter of Part 1 of the report, "Needs and Resources". Between 1940 and 1960 , the proportion of scientists and engineers in the working population greatly increased, and now, at 1.7 million, exceeds 2 per cent. Of this total, about 950,000 are engineers, 500,000 scientists and 250,000 teachers of science or mathematics at the secondary school level. By 1970, the total is expected to reach 2.8 per cent of the working population. About 40 per cent are engaged in private industry or commerce, 20 per cent in education, and between 20 and 30 per cent in work affecting national security and its position in the exploration of space. No major division of science includes more than 7.5 per cent of the scientists and no branch of engineering more than 15 per cent of engineers. Of those with doctorates, $29 \cdot 2$ per cent are scientists, $15 \cdot 1$ per cent being in the physical sciences and 7.4 per cent in the biological sciences. Secondary school teachers account for 14.7 per cent and engineers for $56 \cdot 1$ per cent; 6.7 per cent are psychologists or social scientists. Two out of three scientists and two out of five engineers are engaged in research and development. It is estimated that in 1963, of the total graduates in science and engin-
\end{abstract}

* Towards Better Utilization of Scientific and Engineering Talent: a Program for Action. Report of the Committee on Utilization of Scientific and Engineering Manpower. Publication No. 1191, National Academy of Sciences. (Printing and Publishing Offices, National Academy of Sciences, Washington, D.C., 1964.) eering, 57 per cent were employed in industry, 11 per cent by the Government, 12 per cent in colleges and universities and 15 per cent as secondary school teachers.

These figures and profiles are supported in Part 2 of the report by nine study papers. Mr. F. H. Harbison discusses measures towards the development of a comprehensive man-power policy; G. Colm and L. A. Lecht outline requirements for scientific and engineering manpower in the 1970's; and A. M. Ross considers how the United States uses its engineers and scientists. Proposals for development of an improved man-power-related information programme are detailed by A. O. Gamble, while P. W. Charington considers the impact of Government policy and action on the utilization of scientific and engineering man-power in the acquisition of weapons and space systems in a paper entitled "Systems-Acquisition and the Utilization of Scientific and Engineering ManPower (Requirements and Programme-determination, Contracts and Grants)". In a further paper, he submits two case studies of the utilization of scientific and engineering man-power in the major military systems, Titan II and Naval Tactical Data Systems: this is summarized and its principal findings only are presented. In the last three papers, A. B. Kinzel presents an industrial view of the Government's impact on civilian research and developmont man-power, L. M. Hartman describes industrial practice affecting the utilization of scientific and engineering man-power, and R. H. Bolt takes a look ahead at man-machine partnership in intellectual pursuits.

\section{FILM AND TELEVISION IN THE WORK OF THE UNIVERSITIES}

A ONE-DAY conference on the film and television in the work of the universities was held at the Royal College of Art, London, on July 21. Mr. Michael Clarke, tutor in the Department of Television and Film at the College, deserves every praise and admiration for arranging the meeting. The interest and enthusiasm shown by his audience were a welcome indication that audio visual media may shortly emerge from their adolescence.

The British Universities Film Council conference at Senate House in March, 1963, set out to survey the field of closed-circuit television within institutions of higher education from the severely practical point of view of application, technique, instrumentation and cost. At the Royal College of Art, Members of Parliament, university vice-chancellors and professors, members of the University Grants Committee Sub-committee on Audio Visual Aids Facilities in Higher Education, directors and senior executives of the independent television companies and of the B.B.C., as well as a catholic selection of experts in the arts and scionces came together to hcar and to discuss a wide-ranging and more general search for the present and future role of film and television in the universities.

In opening tho morning's session on "Potential Functions of Film and Tolevision in Higher Education", Mr. Clarke pointed out that the moeting was too large to achieve any concreto results and that the main aim should be to gain information from each other. The Television and Film Department within the Royal College of Art would accept up to ten studonts a year who had completed their art-school training. They would go through a threcyear course on film and closed-circuit television to learn how to think in terms of moving pictures. From among these students, it was hoped, would come some of the producers and directors of the future. A one-year course exists for those who are already in industry but wish to experiment or enlarge their knowledge. The nucleus of an academic film unit has been created and has started to make teaching films in collaboration with Imperial College of Science and Technology, London.

Mr. Clarke claimed that film and television should be regarded as modes of communication in their own right. If thoy were to be fully exploited in this way, both users and producers would have to rethink and learn how to use visual concepts. This should apply not only to the professionals but also to the teachers; all should learn to think in terms of illustration.

Prof. Collin Cherry, Department of Telecommunication, Imperial College, and author of On Human Communication (John Wiley and Sons and Science Editions, Inc., 1961), spoke on his experimental use of simple closed-circuit television equipment as an enlarging device during his lectures on engineering, where this device enabled him to use small models to illustrate abstract concepts. He also recorded a twenty-minute summary immediately after cach lecture, so that his students could listen to the taperecording either to supplement their notes or to catch up on a lecture they might have missed.

Prof. Cherry emphasized that the academic lecture should impart a basic understanding and interest in the subject, not detailed information. He expressed the hope that television would cut its traditional cinema apron strings and make greater use of its essentially electronic genes. Future use of television in the lecture theatre might bring outside events and phenomena to the student to 